\title{
Water Consumption Pattern of Jaipur City (India)
}

\author{
Jethoo, A. S. and Poonia, M.P
}

\begin{abstract}
In the past few years, ground water level in India as a whole and in Rajasthan, in particular is going down. The State is facing a drought like situation. Ninety nine percent dams of Rajasthan are completely or are at the verge of drying. Major cities like Jaipur is facing tremendous problem of drinking water. In last few years, the population of Jaipur city has been increased exponentially, leading to acute shortage of drinking water. Unfortunately, with diminishing resources of drinking water, the human behavior towards water conservation is not changing. During present study efforts have been made to assess the different income group consumer's behavior with respect to the dwindling water supply. It has been observed that due to little awareness, people are using much more water than it is needed. This needs to be addressed immediately by changing public perception towards water use through media and by organizing public awareness programs. It is hoped that the results of the study would benefit the urban development authorities in optimizing the existing water resources through proper distribution system viz a viz society.
\end{abstract}

Index Terms - Consumption, Water supply, Water savings.

\section{INTRODUCTION}

The colorless, odorless, and tasteless liquid known as water is essential for all sorts of growth and development of human kind, animals and plants. Since water is a key resource and we can never create more water, water management deserves priority in the development and preservation of any area.

It is a matter of serious concern that $97 \%$ of the total water available on the Earth is salty, and only 3\% is fresh water of which slightly over two thirds is frozen in glaciers and polar ice caps. The remaining unfrozen fresh water is mainly found as groundwater, with only a small fraction present above ground or in the air

Fresh water is getting increasingly scarce in the world. Earlier, the common perception was that water was an infinite resource. That time, there were only half the current number of people on the planet. Even people were not as wealthy as today, used to consume only fewer calories and ate less meat, so less water was needed for the production of their food. They required one third of the water we presently take from rivers or underground. Today, the consumption of water resources is much more intense. This is because there are nearly seven billion people on the planet; their consumption of eatables like meat and vegetables is rising. Further, there is huge competition for water consumption

Manuscript received March 30, 2011.

Jethoo, A. S. ,Associate Professor,Department of Civil Engineering, Malaviya National Institute of Technology Jaipur, India

Poonia , M.P,Professor,Department of Mechanical Engineering, Malaviya National Institute of Technology Jaipur, India e-mail: jethoo@rediffmail.com from industrial sector, urbanization and agricultural crops. In future, even more water will be needed to produce food because the Earth's population is forecast to be rise to 9 billion by the end of year $2050\{2\}$.

At present, the most pressing problem before humanity is not the fear of outbreak of war, epidemic or the collapse of civil administration but the daunting problem of short supply of drinking water [1]. India has been always fortunate in having abundant fresh water reserves, but the increasing population and overexploitation of surface and ground water over the past few decades has resulted in water scarcity in many regions of the country.

Rajasthan has been urbanizing rapidly in recent decades. The urban population in Rajasthan will nearly double from 13.2 million in 2001 to 24 million in 2026 [3]. This steep increase in population will increase the number of those living below the poverty line already the incidence of such people is higher in cities and towns than in the villages of Rajasthan [4].

Jaipur, popularly known as pink city is also known for its beautiful architectural planning and historicity. Most of the population is occupied in industries, commerce \& trade and government or private services. Agriculture and mining activities are negligible in the city; therefore employ a lesser number from the work force as shown in Fig. 1.

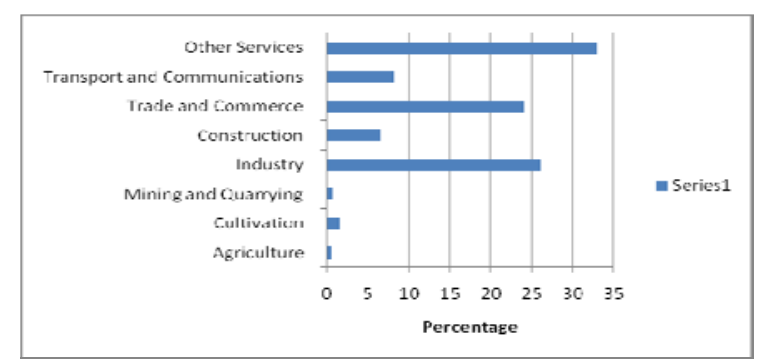

Fig 1: Occupation Structure of Jaipur City

Due to capital city of Rajasthan state has been selected as the study area for consumer behavior. The climate is semi arid and average rainfall is only $556.4 \mathrm{~mm}$. The rainy season lasts from June to September. The temperature varies from 25.80 C to $450 \mathrm{C}$ in summer months and from $8.30 \mathrm{C}$ to 220 $\mathrm{C}$ during winters. The city experienced a swift rise in population from 0.160 million in 1901 to 2.32 million in 2001. This growth rate of population is given in Fig.2.

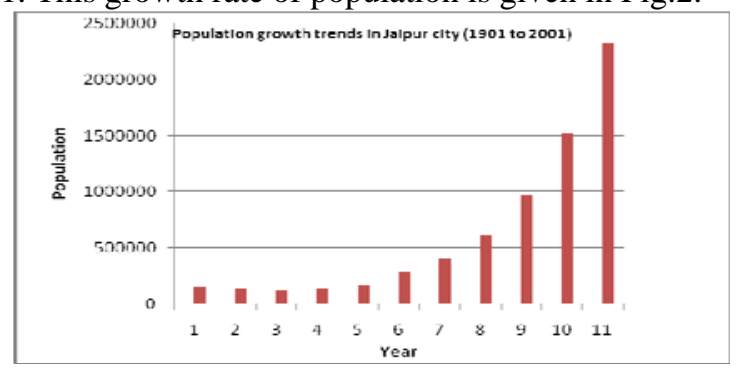

Fig. 2: Population growth trends in Jaipur city 
Better understanding of consumer behavior could help in developing newer strategies for successful marketing of water as a social and an economic commodity for enhancing the sustainability of water supply. Consumer behavior studies have widespread application in the marketing of goods and services and the application of some of these concepts could be useful in improving delivery of water services [5].

The main objective of the present study is to assess and analyze the behavior of water users in urban areas like Jaipur. The problem of domestic use of water becoming complex and complex due to its availability is contingent only in the monsoons, which over the time is becoming scarce, highly unpredictable and erratic. Same time recharging of ground water has also not been planned by competent authorities leading to a serious area concern. The results and findings of the present study would benefit the urban development authorities, municipalities, other governmental and non government organizations in optimal planning of available water resources.

\section{Methodology AND StUdy AREA}

Jaipur is largely spread so selecting the appropriate area of study was also found to be difficult. After thorough considerations of density of population and spread of various income groups, an exhaustive questionnaire was administered to the city dwellers in that area to obtain required useful data. The categorization of incumbents was done on the basis of a certain monthly income such as those in the Lower Income Group (LIG) having a monthly income up to `5000, Lower Middle Income Group (L-MIG) whose monthly income ranges from `5000 to `15000, the Upper Middle Income Group (U-MIG) in the monthly earnings of $` 15000$ to 30000 and the Higher Income Group (HIG) whose income excess `30000.

More than 400 questionnaires were dispatched as well as handed over personally to respondents, out of which only 225 respondents could reply. However, the sample size was smaller for such an important study of concern, but the limitation was availability of time and resources. The response rate was also poor despite of frequent and regular reminders.

\section{OBSERVATIONS AND FINDINGS}

Mode of garbage collection in the selected houses also been looked into. Garbage collection in the Jaipur city is the responsibility of Municipal Corporation. It been noticed that garbage collection of about $28 \%$ houses is done through locally hired private agencies whereas $72 \%$ of household waste goes in unplanned manner into central drainage system. This creates a severe nuisance in waste disposal system. The collected data is shown in Table 1.
TABLE I. MODE OF GARBAGE COLLECTION AND WASTE WATER DISPOSAL

\begin{tabular}{|c|c|c|c|c|c|c|c|c|}
\hline \multirow{2}{*}{$\begin{array}{c}\text { Type } \\
\text { of } \\
\text { houses }\end{array}$} & \multicolumn{4}{|c|}{ Mode of garbage collection } & \multicolumn{4}{|c|}{$\begin{array}{l}\text { Waste water disposal } \\
\text { system }\end{array}$} \\
\hline & & 营 & 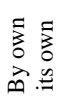 & 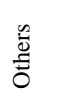 & 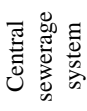 & 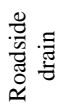 & 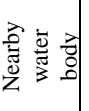 & 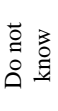 \\
\hline LIG & 6 & 3 & 3 & 0 & 6 & 0 & 0 & 6 \\
\hline L-MIG & 30 & 3 & 0 & 9 & 36 & 6 & 0 & 0 \\
\hline U-MIG & 69 & 36 & 33 & 0 & 96 & 27 & 6 & 9 \\
\hline HIG & 9 & 21 & 3 & 0 & 24 & 9 & 0 & 0 \\
\hline Total & 114 & 63 & 39 & 9 & 162 & 42 & 6 & 15 \\
\hline
\end{tabular}

After assessing the waste disposal system, study was concentrated over the water needs of the town by using the developed questionnaire. The daily consumption data of water is collected for indoor as well as outdoor consumption separately. The data of water consumption for domestic animals and for kitchen garden was also obtained. The common household use of water is taken as a whole whereas individual usages are multiplied with the average size of household of different descriptions such as LIG, L-MIG, UMIG and HIG and then liters per capita consumption was obtained and presented in Table 2 and Fig 3 whereas the average number of members per household is get through the questionnaire. The average number of persons per household is five for the majority of samples. The size of house or members per household is shown in Fig 4.

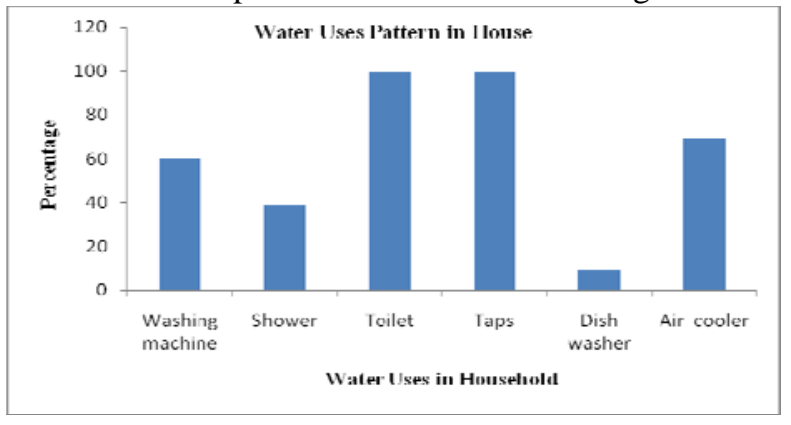

Fig 3: Water uses pattern in house

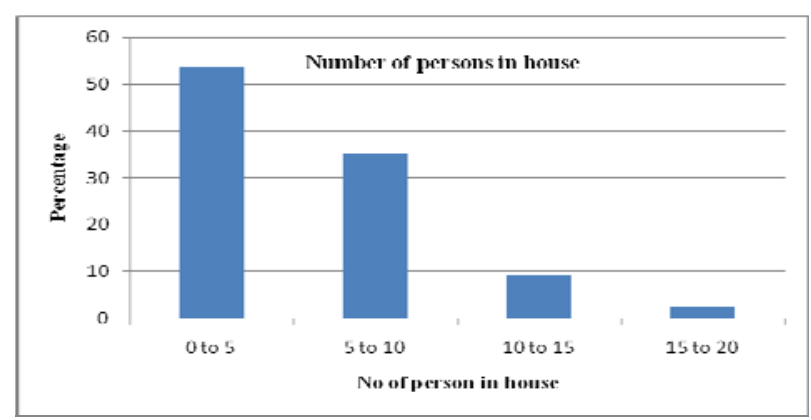

Fig 4: Number of persons in house

TABLE II. WATER USAgE PATTERN IN A HoUse

\begin{tabular}{|l|r|r|r|r|r|r|}
\hline $\begin{array}{c}\text { Type of } \\
\text { households }\end{array}$ & $\begin{array}{c}\text { Washing } \\
\text { machine }\end{array}$ & Shower & $\begin{array}{c}\text { Toil } \\
\text { et }\end{array}$ & Taps & $\begin{array}{c}\text { Dish } \\
\text { washer }\end{array}$ & $\begin{array}{c}\text { Air } \\
\text { coo } \\
\text { ler }\end{array}$ \\
\hline LIG & 0 & 6 & 12 & 12 & 0 & 0 \\
\hline L-MIG & 15 & 9 & 42 & 42 & 0 & 36 \\
\hline U-MIG & 93 & 60 & 138 & 138 & 18 & 93 \\
\hline HIG & 27 & 12 & 33 & 33 & 3 & 27 \\
\hline Total & 135 & 87 & 225 & 225 & 21 & 156 \\
\hline
\end{tabular}


In majority of houses, dogs have been found to be the favorite among pet animals whereas birds are pets as rarest. However, in the case of feeding water to pets found to be optimally used because good quality utensils are being maintained which is leak proof. The water requirement is observed to be negligible for these and not accounted for separately. The frequency of watering the plants in the individual home garden is represented in Fig.5

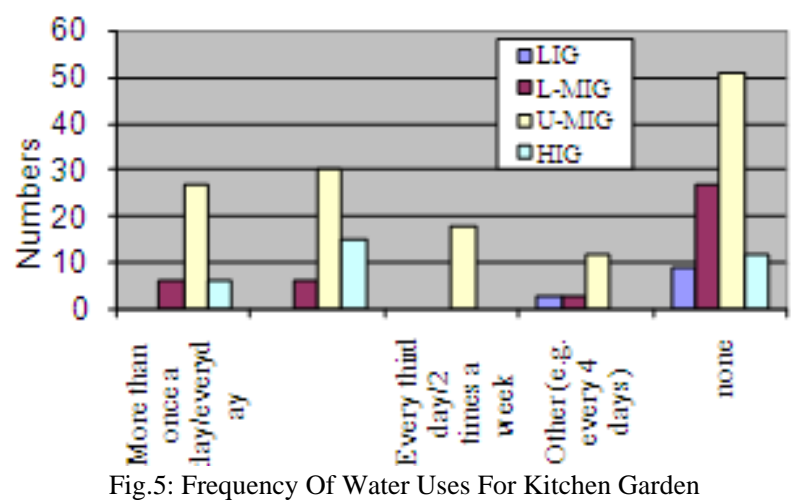

As shown in Table 3, half of the households consume only 20 liters of water per day while one-third households use 20 to 40 liters. Around two thirds households consume water drawn directly from the taps without any treatment at their end. Majority of the households assumes that the water qualities standards are being maintained by Municipal Corporation are as per IS-10500-1991. The Fig 6 shows daily drinking water consumption pattern.

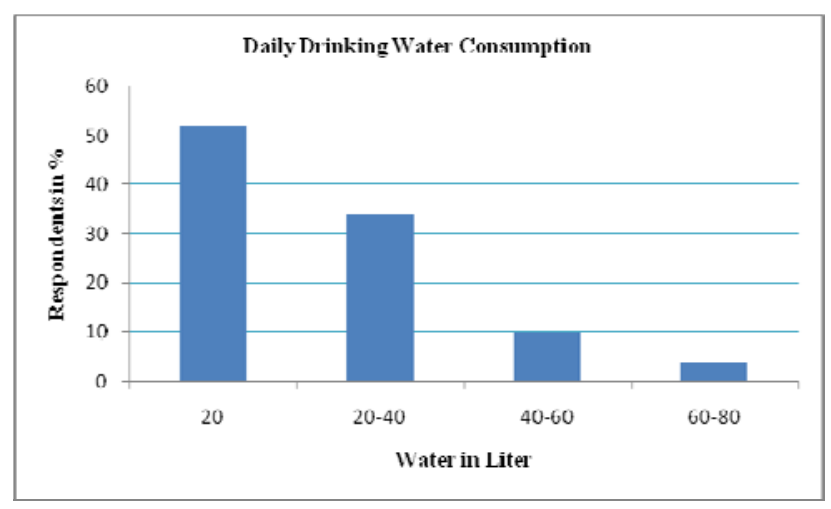

Fig 6: Daily drinking water consumption

TABLE III. DAILY DRINKING WATER CONSUMPTION

\begin{tabular}{|c|c|c|c|c|c|c|}
\hline \multirow{2}{*}{$\begin{array}{c}\text { Type of } \\
\text { households }\end{array}$} & \multicolumn{4}{|c|}{$\begin{array}{l}\text { Daily drinking water consumption in } \\
\text { liters }\end{array}$} & \multicolumn{2}{|c|}{$\begin{array}{l}\text { Directly obtained } \\
\text { water through tap }\end{array}$} \\
\hline & 20 & $20-40$ & $40-60$ & $60-80$ & Yes & No \\
\hline LIG & 12 & 0 & 0 & 0 & 12 & 0 \\
\hline L-MIG & 27 & 15 & 0 & U & 27 & 15 \\
\hline U-MIG & 63 & 45 & 24 & 6 & 93 & 45 \\
\hline HIG & 15 & 15 & 0 & 3 & 15 & 18 \\
\hline Total & 117 & 75 & 24 & 9 & 147 & 78 \\
\hline
\end{tabular}

Next study was concentrated over the water use behavior, laundry use, water saving mentality and prevalent practices by the households. The Table 4 shows data on household water use.
TABLE IV. HOUSEHOLD WATER USE PATTERN

\begin{tabular}{|c|c|c|c|c|c|c|c|c|c|}
\hline \multirow[b]{2}{*}{ 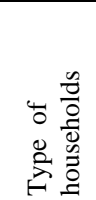 } & \multicolumn{9}{|c|}{ Household Usage } \\
\hline & 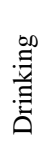 & ن & 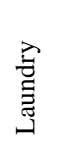 & 泀 & 离 & 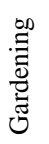 & 茪 & 离 & 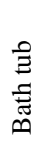 \\
\hline LIG & 12 & 12 & 12 & 12 & 12 & 0 & 0 & 0 & 0 \\
\hline L-MIG & 42 & 42 & 15 & 42 & 30 & 0 & 6 & 21 & 3 \\
\hline U-MIG & 138 & 138 & 114 & 138 & 126 & 45 & 51 & 45 & 6 \\
\hline HIG & 33 & 33 & 24 & 33 & 33 & 12 & 18 & 9 & 3 \\
\hline
\end{tabular}

It has been observed that the washing machines for laundry have been the dominating in the U-MIG and in HIG owing to the healthy paying capacity for such luxury items. The observations are shown in Table 5

TABLE V. MODE OF LAUNDRY \& WATER SAVING MEASURES

\begin{tabular}{|l|r|r|r|r|}
\hline \multirow{2}{*}{\begin{tabular}{c}
\multirow{2}{*}{$\begin{array}{c}\text { Type of } \\
\text { households }\end{array}$} \\
\cline { 2 - 5 }
\end{tabular}} & \multicolumn{2}{|c|}{ Laundry method } & \multicolumn{2}{c|}{$\begin{array}{c}\text { Water conservation } \\
\text { measures }\end{array}$} \\
\cline { 2 - 5 } LIG & 12 & \multicolumn{1}{c|}{ Machine } & Adopted & Not adopted \\
\hline L-MIG & 30 & 0 & 0 & 12 \\
\hline U-MIG & 54 & 12 & 27 & 15 \\
\hline HIG & 9 & 84 & 78 & 60 \\
\hline Total & 105 & 24 & 18 & 15 \\
\hline
\end{tabular}

More than half of the respondents stated that they were adopting water saving measures. Nevertheless, further water saving measures is needed to alleviate the situation of water scarcity. This can be achieved by imposing the heavy tariff based on water consumption for the households who consume more than what is already been allotted by the competent authorities. The obtained data for water saving is given in Table 6 .

TABLE VI. WATER SAVING MEASURES ADOPTED BY HOUSEHOLD

\begin{tabular}{|c|c|c|c|c|c|c|c|}
\hline \multirow[b]{2}{*}{$\begin{array}{l}\text { Category of } \\
\text { households }\end{array}$} & \multicolumn{7}{|c|}{ Water saving measure in household } \\
\hline & 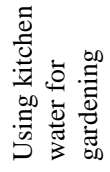 & 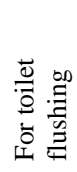 & 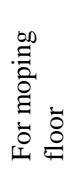 & 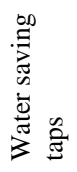 & 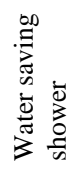 & 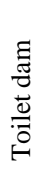 & $\begin{array}{l}\mathscr{\Xi} \\
\text { 乙o }\end{array}$ \\
\hline LIG & 0 & 0 & 0 & 0 & 0 & 0 & 12 \\
\hline L-MIG & 15 & 21 & 3 & 3 & 3 & 0 & 15 \\
\hline U-MIG & 36 & 27 & 15 & 12 & 0 & 9 & 60 \\
\hline HIG & 9 & 3 & 6 & 6 & 3 & 3 & 15 \\
\hline
\end{tabular}

On the basis of study of water consumption, the water quantity assessment of consumer behavior of city dwellers of Jaipur in liters per capita per day is given below in Table 7.

The U-MIG income groups have a habit of maintaining small gardens in front of their houses which increases the water requirement of this group. Households in the upper income group use higher quantity of water for washing clothes, due to ease of washing with machines, at home.

TABLE VII. WATER CONSUMPTION IN LITER PER DAY

\begin{tabular}{|r|l|r|r|r|r|}
\hline S. No. & Use & \multicolumn{1}{c|}{ LIG } & L-MIG & U-MIG & \multicolumn{1}{c|}{ HIG } \\
\hline 1 & In house & 103.0 & 105.3 & 121.3 & 116.6 \\
\hline 2 & Drinking & 1.1 & 2.7 & 5.5 & 3.7 \\
\hline 3 & Cooking & 2.0 & 2.0 & 3.0 & 4.0 \\
\hline 4 & Gardening & 8.0 & 10.0 & 12.0 & 15.0 \\
\hline \multicolumn{2}{|c|}{ Total } & 114.1 & 120.0 & 141.8 & 139.3 \\
\hline
\end{tabular}




\section{IV.CONCLUSIONS}

On the basis of present study, following salient conclusions have been drawn;

1. This study has shown that water use in the household is highly correlated with the income of different groups. Maximum water consumption is observed in HIG and MIG incumbents.

2. Only HIG and MIG incumbents are responsible for large water consumption in kitchen garden and car washing.

3. Changes in lifestyle are contributing to the rise in consumption.

4. Water use is also affected by climate change, since rising temperatures lead to increase in water consumption for gardening and personal comfort such as desert coolers.

5. Several domestic water saving measures can be adopted. Technical measures like changes in water supply, improving maintenance, installation of some water saving devices, etc.

6. Information dissemination, education, higher tariff may change consumptive habits.

7. Effective rebate may also been successful in reducing water use.

\section{REFERENCES}

[1] P.L. Arora, "Water management a global perspective", two weeks STTP, MNIT Jaipur, March 2007.

[2] Asian Development Bank, "Water utilities data book: Asian and Pacific region” 1993.

[3] Census of India 2001

[4] Asian Development Bank, "Second water utilities data book: Asian and Pacific region” 1997.

[5] J.J. Boland, "Pricing urban water: Principles and compromises", World Bank seminar on pricing of sanitation and water services, February 18-19, 1997.
[6] Jethoo, A.S, “Consumer Behaviour of Urban Residents of Jaipur City (India) for Water Supply, International Conference on Environmental Science and Technology (ICEST 2011), Singapore, February 26-28, 2011.

[7] Jethoo A.S, Poonia M.P, "Sustainable Water Supply Policy for Jaipur City” International Journal of Environmental Sciences (ISSN 0976 4402), Volume 1, No 6, 2011, pp.1235-1240

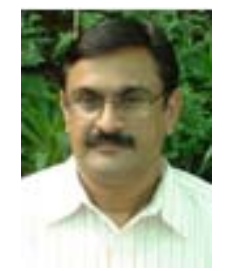

A.S. Jethoo was born on September 25, 1961 in Rajasthan, India. He earned his Ph. D. degree in Water resources engineering from University of Rajasthan, Jaipur, India in 2005. His major area of specialization is Water Resources and Environment.

$\mathrm{He}$ is working as Associate Professor, Civil Engineering Department at Malaviya National Institute of Technology Jaipur, India. He has more than twelve years of teaching and research experience at undergraduate and postgraduate level. He has published more than twenty research papers in the journals of national and international repute.

Dr. A.S. Jethoo is a life member of Indian Water Resource Society, Member of Institution of Engineers, India (IEI) and Senior Member of the APCBEES

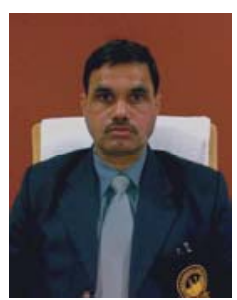

M. P. Poonia was born on July 7, 1959 in Rajasthan, India. He earned his $\mathrm{Ph}$. D. degree in Thermal Engineering from Indian Institute of Technology Delhi, India in 1997. His major area of specialization is Internal Combustion Engines and Alternative Fuels.

$\mathrm{He}$ is working as Professor, Mechanical Engineering Department at Malaviya National Institute of Technology Jaipur, India. He has more than twenty five years of teaching and research experience at undergraduate and postgraduate level. He has published more than fifty research papers in the journals of national and international repute. He has written/edited eight books and guided at least thirty research projects.

Prof. M.P.Poonia is a life member of Society of Automotive Engineers (SAE), life member of Indian Society of Technical Education (ISTE) and Institution of Engineers, India (IEI). He has been awarded by Government of Rajasthan, India in the year 2008 for his excellent services. 